\title{
Assessment of Smallholder Farmers' Adaptive Strategies on the Effects of Seasonal Rainfall Variability on Maize Yields in Nyeri County
}

\author{
Lilly N. Kabata ${ }^{1}$, George L. Makokha ${ }^{1} \&$ Kennedy Obiero ${ }^{1}$ \\ ${ }^{1}$ Department of Geography, Kenyatta University - Nairobi, Kenya \\ Correspondence: Lilly N. Kabata, Department of Geography, Kenyatta University - Nairobi, Kenya.
}

Received: December 13, 2021; Accepted: December 30, 2021; Published: December 31, 2021

\begin{abstract}
Maize is the leading food crop produced in most parts of the world and a staple food crop in Kenya. Majority of the maize farmers are smallholders due to reduced land sizes as a result of land fragmentation. Maize farming is rain-fed making it more vulnerable to rainfall variability. Over the years, the farmers have increased their resilience and adaptive potential through indigenous knowledge so as to cope with the climate related risks. However, the increasing rainfall variability, frequency and more severe shocks likely surpass their current adaptive strategies. The study assessed existing adaptive strategies of the small-holder maize farmers in Kieni East sub-County in Nyeri Couny to the seasonal rainfall variability effects. The research adopted a mixed research design. Data was obtained from primary and secondary sources. Primary data was obtained using household structured questionnaires. Data was analyzed using descriptive methods and presented using charts and tables. SWOT analysis analyzed several underlying aspects affecting maize farmers in the sub-County. The study found that the farmers have several specific adaptive strategies to the effects of seasonal rainfall variability at their disposal which include but not limited to the use of varieties of maize seeds, seeking training, water harvesting, use of manure and fertilizers. Farmers also respond to rainfall variability by planting maize varieties that are early maturing and drought resistant as well as engaging in alternative farming activities and other economic activities.
\end{abstract}

Keywords: rainfall variability, maize yield, adaptive strategies, Nyeri County

\section{Introdution}

Climate variability will continue to be an issue for rural communities that rely on agricultural production. Communities have long been adapting to climate change, but these adaptations are typically discrete and reactive [55]. Adaptation to climate variability refers to adjustments in the system to minimize the negative impacts and optimize the positive impacts of climate variability. Globally, technical advancements have given farmers the ability to adjust to climate circumstances over time. Depending on their long-term experiences and subjective assessments of risks, farm households continuously develop adaptive strategies to environmental and socioeconomic changes as part of their production and consumption decisions [52]. It has been recognized that sustainable adaptation measures can reduce negative impacts of climate variability on agricultural production [25]. Studies have demonstrated that different asset bases can lead to divergent adaptation strategies among households in a single community [24]. Adaptation strategies have been derived from the Sustainable Development Goals (SDGs) numbers 2 and 13 of the United Nations which addresses zero hunger and climate action respectively.

Agriculture is a key occupational sector in many Sub-Sahara Africa (SSA) nations and a source of income for the rural population [56]. Maize is grown on around 100 million hectares in the developing countries, according to estimates. According to [12], the medium and lower income earners account for almost $70 \%$ of total maize yield in these nations. Rain-fed agriculture accounts for about $90 \%$ of all staple food production in this region. [8]. The region is highly vulnerable to adverse impacts of climate change and variability [39]. Increased temperatures coupled with erratic rainfall and uncertainties about the onset of the rains have significant implications for the livelihoods of millions of people [11]. Without appropriate adaptation, this variability will exacerbate current vulnerabilities and present challenges for many rural households [22]. The relationship between risk perception, socio-economic restrictions, and adaptation activity has not been fully examined in this region. Understanding the decision-making process of farmers is critical for forecasting future behavior and appreciating the factors that influence the process [29]. 
The majority of Kenyan households farm maize, the country's principal staple crop that sustains over $85 \%$ of the population [34], on approximately $17 \%$ of the country's geographical area [57]. Smallholder rain-fed agricultural systems (averaging $0.2-0.3$ hectares in size) account for $75 \%$ of overall agricultural output and $70 \%$ of marketable agricultural commodities in the country [19,5]. Smallholders in most sections of the country, however, see rainfall variability as a threat to agricultural productivity [5]. The peoples' ability to maintain food security in the face of climate change and variability will thus depend significantly on their adaptive strategies. The smallholder farmers are more vulnerable to the effects of rainfall variability due to their low adaptive capacity. Kenya's government recognizes that adaptation to climate change and variability is the country's top goal in its Climate Change Adaptation Strategy 2009-2030. When it comes to national food security, adaptability to rainfall variability is very absolutely essential. [17]. Lack of resources, poor water access, and a lack of awareness are all important impediments to the adoption of more expensive farming practices [5]. Simple interventions, such as adjusting planting dates [42, 17], are routinely applied, whereas modifications in water or land management methods, such as installing an irrigation system or implementing agro-forestry, are under-utilized [5]. Age, gender, agricultural experience, and education have all been found to have an impact on the adoption of specific adaptation strategies [4]. Cultivating high-value crops in mixed farming systems may allow farmers to take advantage of high market prices during dry seasons, raise their income, and improve their drought resilience [58]. Such solutions, however, are confined to places with sufficient water supply and irrigation systems [6].

Kenya's government realizes that adaptation to climate change is the country's top concern. When it comes to national food security, the agricultural sector, in particular, plays a critical role [17]. To maintain the recent favorable agricultural growth, defend the national economy, and protect rural livelihoods, a number of programs, policies, and governmental organizations have been launched, an example being the National Drought Management Authority (NDMA) in 2011. Drought impacts in arid and semi-arid areas (ASALs), which are especially vulnerable to climate change and home to $30 \%$ of the country's population, are given special attention [17] and also where Kieni East sub-County in Nyeri County is situated. Adaptation to climate variability requires that households appreciate that there exists climate variations and recognize useful adaptation options, choosing among a wide range of strategies at their disposal. Hence, households within the same geographical location use different adaptation strategies in response to climate variability due to their capability [30]. Although these measures exist on paper, the majority of Kenya's smallholder farmers have yet to reap the rewards. Many of these national programs have been chastised for failing to use locally available information and technologies [42]. Furthermore, scientific literature rarely addresses climate change perception as it relates to adaptive behavior at the individual farm level. Climate change impacts and adaptation options are frequently assessed using aggregated data from country or regional levels in research [60]. Simultaneously, there is a substantial body of literature devoted to the effects of climate change on individual crops at the field scale [52, 47]. The goal is to generate generalizable data that can be used by adaptation planners to encourage widespread adoption of better farming techniques. However, the findings thus are extremely aggregated, and the examined criteria are of limited use to local adaptation planners or farmers.

Micro-level information is desperately needed to allow policymakers and extension officers to adapt national programs to local realities and promote focused interventions, a fact that prompted this study. Food productivity can be improved with proper adaptations at household level [10]. It is however important to invest in adaptation measures at national, county and farm level. Many sections of the country still lack proper institutional framework conditions, leaving resource-poor smallholder farmers fighting climatic and economic difficulties on their own. This is the case in the Kieni East sub-County. Existing programs are either useless, corrupt, or benefit only a limited number of people who are already well-off. Traditional adaptive techniques in the country, and notably in Kieni East sub-County, Nyeri County, are likely to be overwhelmed by increased frequency of rainfall variability and shocks. As a result, there is a need to better understand, document, and reinforce existing adaptation techniques. It is with these factors in mind that the purpose of this research was to assess the existing adaptive strategies of the small holder maize farmers' in Nyeri County's Kieni East sub-County, to the seasonal rainfall variability effects, as it is also the decision-making of the smallholder farmers at micro-level that matters in improving maize yields.

\subsection{Study Area}

The study was conducted in Kieni East sub-County, Nyeri County. The sub-County is made up of four wards, namely; Narumoru/Kiamathaga, Kabaru, Thegu and Gakawa. It has a population of 96,500 people and 29,012 households KNBS, [27]. It is extensive and occupies about $817.1 \mathrm{Kms}^{2}$ [17]. The sub-County lies between $0^{0} 00^{\prime}$ to $0^{\circ} 24^{\prime} \mathrm{S}$ and $37^{\circ} 00^{\prime}$ to $37^{\circ} 12^{\prime} \mathrm{E}$. It borders Meru central sub-County to the North, Mathira sub-County and Nyeri municipality to the south, Mt. Kenya to the East and Kieni west sub-County to the west according to the map of the study area fig 1. Land size per household varies across the sub-County but with an average of 2 ha [23]. Land 
ownership is predominantly free hold and the majority of the farms are small scale. The growing seasons are largely determined by rainfall patterns, the two distinct rainy seasons are from March to May (MAM) and October to December (OND), with average yearly rainfall ranging from 500 to 850 millimeters. [32]. [23] classified the area into four main agro-ecological zones namely; Tropical-Alpine, Upper Highlands, Lower Highlands and Upper Midlands. It should be emphasized that these agro-ecological zones are mostly based on climate data with insufficient consideration of soil characteristics, which is why Kieni [59] grows very little coffee and tea. The lowest point is 1500 meters, while the highest point is 2400 meters in the Kabaru forest reserve. Kiganjo and Naromoru, both in agro-climatic zones V and VI, are the driest places. Variations in relief, temperature, and underlying rock types have influenced the soils, making them complex. Fibric histosols, humic andosols, humic nitosols, luvic phaenozems, vertisols, fluvisols, and gleysols are among the primary soils [49]. Maize is the principal food crop grown, and it is recognized as a key staple food by the population, contributing $80 \%$ of the food supply in the form of coarse grain and flour. According to a joint report published in February by the Kenya Food Security Steering Group (KFSSG) and the Nyeri County Steering Group, (2018).

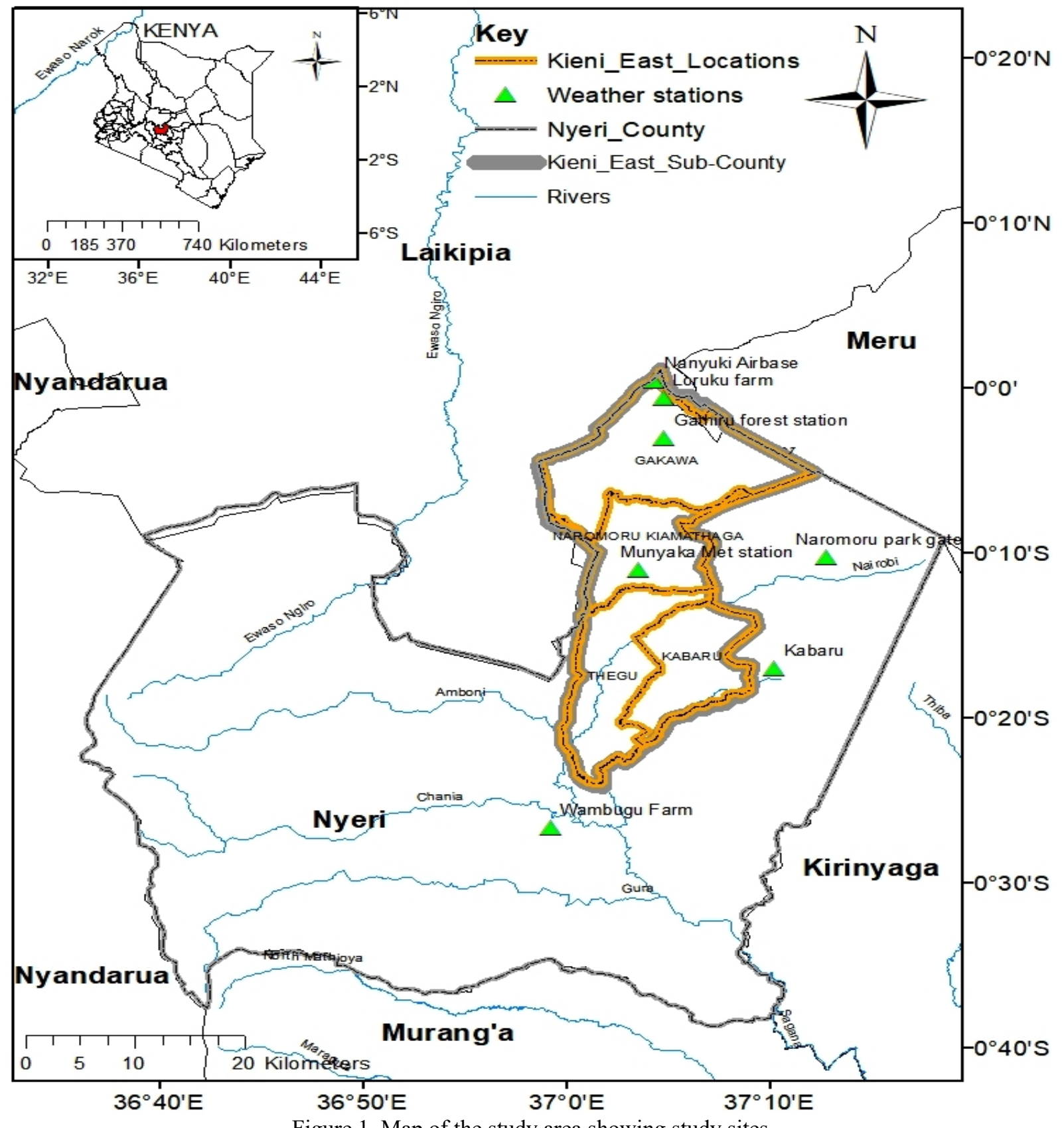

Figure 1. Map of the study area showing study sites

Source: (ESRI, 2017) 


\subsection{Objective of the Study}

To assess the existing smallholder farmers' adaptive strategies to the seasonal rainfall variability effects on maize yields in Kieni East sub-County, Nyeri County.

\section{Methods and Materials}

The study adopted a mixed research design. Data was obtained from both primary and secondary sources. Primary data was obtained using household structured questionnaires. The open-ended questions were chosen to address bias-prone problems such as farmers' perceptions of rainfall variability in a sensitive manner. The dependent variables, namely rainfall variability and adaptive methods, were assessed using closed-ended questionnaires. Data was analyzed using descriptive statistics and results presented using charts and tables. A SWOT analysis of the area was also carried out.

\section{Results and Discussion}

\subsection{Farmers Adaptation Strategies to Rainfall Variability}

\subsubsection{SWOT Analysis}

Strengths, weaknesses/limitations, opportunities, and threats faced by smallholder maize farmers in the study area were all evaluated using the SWOT Matrix. It entailed defining the study's objectives, as well as identifying internal and external factors that are favorable and unfavorable to achieving the objectives. Strengths and weaknesses, according to [21], are internal aspects over which you have some influence, whereas opportunities and threats are external elements over which you have no control. which a single person, in this case the farmer, has no control. According to the SWOT matrix on Table 1 the SWOT analysis for this study analyzed several underlying aspects affecting maize farmers in Nyeri County's Kieni East sub-County.

Table 1. SWOT Matrix

\begin{tabular}{|c|c|}
\hline STRENGTHS & WEAKNESSES \\
\hline Farmers were at the prime age. & Insufficient water harvesting strategies \\
\hline Literacy of farmers. & Decline in farm sizes for maize cultivation \\
\hline $\begin{array}{l}\text { Availability of labor based on household size } \\
\text { and Land ownership }\end{array}$ & Inadequate training on maize farming \\
\hline Gender inclusivity & Inadequate capital \\
\hline $\begin{array}{l}\text { Additional income generating activities, } \\
\text { water harvesting, use of manure and fertilizer }\end{array}$ & Inadequate weather data \\
\hline A bi-modal rainfall pattern & Mostly women engaged in farming \\
\hline OPPORTUNITIES & THREATS \\
\hline Various sources of training for farmers & Poor seed qualities \\
\hline Availability of maize seeds from agro-vets & Inadequate rainfall \\
\hline Assistance by the County government & Pests and diseases \\
\hline Varieties of water harvesting activities & Lack of information on modern and efficient adaptive strategies \\
\hline Kenya Meteorological Station(Nyeri) & Farmers not planting according to the seasonal weather changes \\
\hline
\end{tabular}

Source: Field data, 2019

\subsection{Analysis of Strengths and Weaknesses}

The findings in Table 2 show that the population of Nyeri County's Kieni East sub-County is relatively young. The majority (46.1\%) were between the ages of 41 and 60 , with (41\%) between the ages of 21 and 40 following closely behind. Only $0.5 \%$ of the participants were under the age of 20 , while $12.4 \%$ were beyond the age of 60 . This supports a research by [33], which indicated that the average age of a Kenyan farmer is 57 . This indicates that the majority of the farmers in the study area are in that age range. The population is made up of people who are relatively young and have the energy to support farming activities, notably maize farming, as well as any adaptive measures that aid in cultivation. They are also a resource that, when managed correctly, can help reduce the limitations of small land size by adopting intensive agriculture. According to [31], the quantity of experience required to appreciate various components of climate variability that affect agricultural methods is proportional to the age of the farmer. Farmers who are older are more likely to have seen the majority of climatic variability difficulties as well as the variability of its variables. As a result, they are more likely to perceive and adjust to rainfall fluctuations. 
The study found that both men and women work in maize cultivation, as shown in Table 2. This supports the findings of [37], who discovered that men and women both farm, with the main variation being the farming activities they engage in. The survey did find, however, that the majority $(56.2 \%)$ of the household heads who participated in the survey were female. It is possible that this is due to the fact that more women are involved in agricultural operations than there are men [40]. These findings further support [46] hypothesis that, as a result of quicker male out-migration, agriculture is increasingly becoming a female-dominated sector, with females bearing the brunt of maize cultivation. The existing labor force has therefore been strained, affecting maize yield in the Kieni East sub-County. Because maize harvests are dwindling, several men relocate in search of alternative sources of income. In the position of household heads, however, there is a gender balance, as neither gender outnumbers the other by more than two-thirds. However, the relatively young population of Kieni East sub-County in Nyeri County, which is made up of more females, as shown in Table 2 suggests that the population of Kieni East subCounty in Nyeri County will grow rapidly over time, leading to further land fragmentation and a decline in maize yields. According to Table 2, the majority of homes (123 (56.6\%) had between 4 and 6 family members, with 74 (34.2\%) having between 1 and 3 individuals. Only 20 people (9.2\%) had more than one. These were used to offer farm labor. In Kenya, labor is a crucial component of agricultural production, with most farmers, especially smallholders, employing traditional farming practices and cultivating the majority of their land by hand. Family members do the majority of the job, with the amount of work depending on family arrangements and the number of hours spent. In addition, seasonal labor demands vary, as do labor attributes such as education and health.

Table 2. Demographic Characteristics of the Respondents

\begin{tabular}{llll}
\hline & Categories & Frequency & Percent \\
\hline Gender & Male & 95 & 43.8 \\
& Female & 122 & 56.2 \\
& Total & 217 & 100 \\
\hline Age (Years) & $<20$ & 1 & 0.5 \\
& $21-40$ & 89 & 41 \\
& $41-60$ & 100 & 46.1 \\
& $>60$ & 27 & 12.4 \\
& Total & 217 & 100 \\
\hline Family Size (members) & $1-3$ & 74 & 34.2 \\
& $4-6$ & 123 & 56.6 \\
& $7-9$ & 20 & 9.2 \\
& Total & 217 & 100 \\
\hline
\end{tabular}

Source: Field data, 2019

Table 3 shows that the majority of respondents (45.2\%) had completed primary school, $39.2 \%$ secondary school, $11.1 \%$ post-secondary education, and $4.6 \%$ had completed informal education. As a result, the level of education in Nyeri County's Kieni East sub-County was evidently low. The majority of the respondents, on the other hand, had the fundamental literacy skills required to interpret farming processes. According to [15], such low levels of education are due to high primary school dropout rates, particularly among girls. It has been determined that the domestic labor market in ASALs consistently fails to appeal to the educated, causing them to migrate. Educated farmers can use adaptive practices and make decisions that increase agricultural productivity, such as asking for finance and using title deeds as security, as well as crop diversity, irrigation, and planting at the right time. Farmers with greater education have better access to adaptation information and are more likely to adapt to climate change [9]. According to Table 3, respondents had supplementary income-generating activities such as business (52.6\%), casuals $(37.3 \%)$, and formally employed (10.1\%) as a strategy to mitigate the effect of rainfall variability. Farmers need money to buy things like certified seeds and fertilizer for their farms. [28] agrees, claiming that monetary constraints and limited land holdings are the two most significant impediments to achieving greater farm incomes and optimal agricultural productivity. Poverty, a lack of solid property rights, a lack of cash, farm size, a lack of technical experience, and off-farm jobs are all listed as hurdles to the adoption of climate variability adaptation measures by [14]. 
Table 3. Socio-economic Characteristics of the Respondents

\begin{tabular}{llll}
\hline & Categories & Frequency & Percent \\
\hline \multirow{3}{*}{ Education Level } & Informal & 10 & 4.6 \\
& Primary & 98 & 45.2 \\
& Secondary & 85 & 39.2 \\
& Post-Secondary & 24 & 11.1 \\
& Total & 217 & 100 \\
\hline \multirow{3}{*}{ Income generating activities } & Formal & 22 & 10.1 \\
& Business & 114 & 52.6 \\
& Casual & 81 & 37.3 \\
& Total & 217 & 100 \\
\hline
\end{tabular}

Source: Field data, 2019

According to Table 4 , the findings indicate that most respondents have very small land sizes, with $52.1 \%$ having between $0-2$ acres, $41.5 \% \quad 3-5$ acres, and just $6.4 \%$ having more than 5 acres. Due to the small land sizes in Kieni East sub-County, farmers must invest as much as possible on the present land to boost productivity because there is limited room for expansion. According to [43], small land area indicates that intensive farming is the only option for increasing production. Because most of maize farming is done on family property that is very small in size, as shown in Table 4, this supports optimization of the land resource compared to leased land. However, as the population grows, there will be greater sub-division of family land through inheritance, as well as a major reduction in area available for settlement. This, in turn, will diminish the amount of land under maize cultivation, resulting in lower maize yields. Furthermore, if land area per household decreases due to population growth, small and fragmented plots may limit the utilization of some viable adaption strategies. Due to the limited land size in Kieni East sub-County, as well as the fact that most farmers rely on rain-fed agriculture, they are forced to optimize maize yields. Furthermore, the issue of land size suggests that cropping strategies must be intensified.

Table 4. Farm Characteristics in Kieni East Sub- County

\begin{tabular}{llll}
\hline & Categories & Frequency & Percent \\
\hline & $0-2$ & 113 & 52.1 \\
& $3-5$ & 90 & 41.5 \\
Farm Size (acres) & $>5$ & 14 & 6.4 \\
& Total & 217 & 100 \\
\hline \multirow{4}{*}{ Land Ownership } & Family Land & 143 & 65.9 \\
& Leased & 21 & 9.7 \\
& Bought & 53 & 24.4 \\
& Total & 217 & 100 \\
\hline
\end{tabular}

Source: Field data, 2019

According to Table 4, most of the respondents (65.9\%), were cultivating maize on family land, while (24.4\%) had purchased the farm, and $(9.7 \%)$ were leasing the land. This means the farmers don't have to pay more for leasing, which would cut into their profit margins. Farmers who cultivate crops on leased property suffer greater losses as a result of rainfall variability, and they are less receptive to adaptation strategies because they are only on the land for a short time. For farm productivity, land and other productive resources must be available and accessible [35]. Farmers who cultivate on family land, as opposed to those who lease property for a limited time, have a better chance of adopting permanent and long-term adaptation techniques to rainfall variability. 


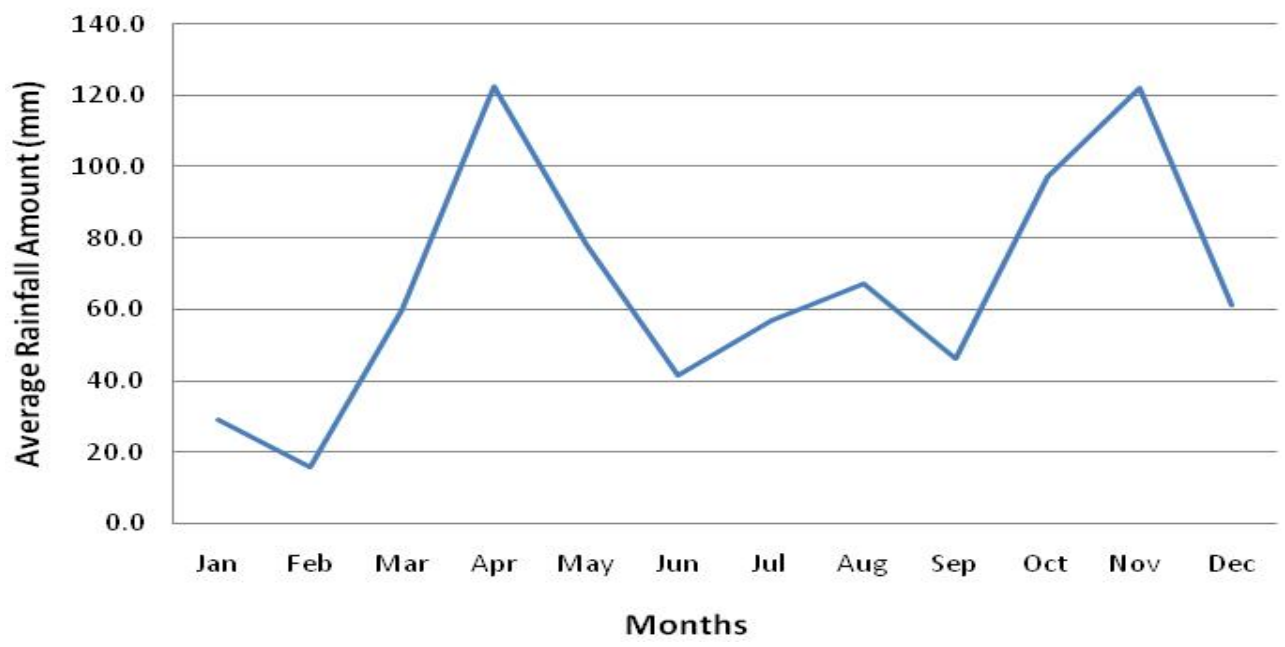

Figure 2. Long-Term MAM and OND Seasons (1988-2018)

Source: Field Data, 2019

Small-holder maize farmers have two rainfall seasons, MAM and OND, according to the area's accessible rainfall data on long-term seasonal rainfall trends (Figure 2), in which crop failure in one season can be compensated by replanting in the next season. Farmers also grow early maturing and drought-resistant maize types, which, when planted at the right time, can result in enhanced yields. In Sub-Saharan Africa, it is a common adaptive strategy [5]. Late planting reduces the chance of being caught off guard by late rainfall. Early planting is done to allow for replanting in the event that the crops do not germinate. Farmers have changed planting dates based on their observations of the wet season over the last few years, which is especially crucial for rain-fed agriculture. Planting at the right time permits the plant to mature before the dry season begins. These findings corroborate those of [42], who discovered that fundamental adaptation strategies like planting date changes and mixed cropping are commonly adopted. Many farmers recognize climatic changes such as changes in the start and end of rainy seasons, increasing rainfall unpredictability,and decreasing rainfall according to studies from South Africa, Kenya, and Uganda $[45,42,48]$. Despite these benefits, maize farming may be discouraged by inconsistent rainfall, low yields, and unpredictably high yield income. Expanding the number of extension staff who can advise farmers on appropriate rainfall variability adaptation measures will help farmers overcome rainfall variability. The Nyeri Meteorological Station's establishment will assist farmers in obtaining accurate weather forecasts and, as a result, planting on time based on the meteorological station's onset dates.

\subsubsection{Sources of Maize Seed}

The study sought to establish where the farmers in the study area sourced their maize seed for planting. The findings in Figure 3 shows that majority of the respondents (98\%) stated that they get maize seed for planting from agro-vets with only $2 \%$ stating that they source them locally. This implies that the farmers are aware that hybrid seeds are better than the locally available ones as the latter put them at more risk of adverse effects of rainfall variability. This is corroborated by [3] who reported that in order to counter the adverse effects of rainfall variability in maize farming, it might be necessary to practice early planting and use of hybrid seeds especially those early maturing ones.

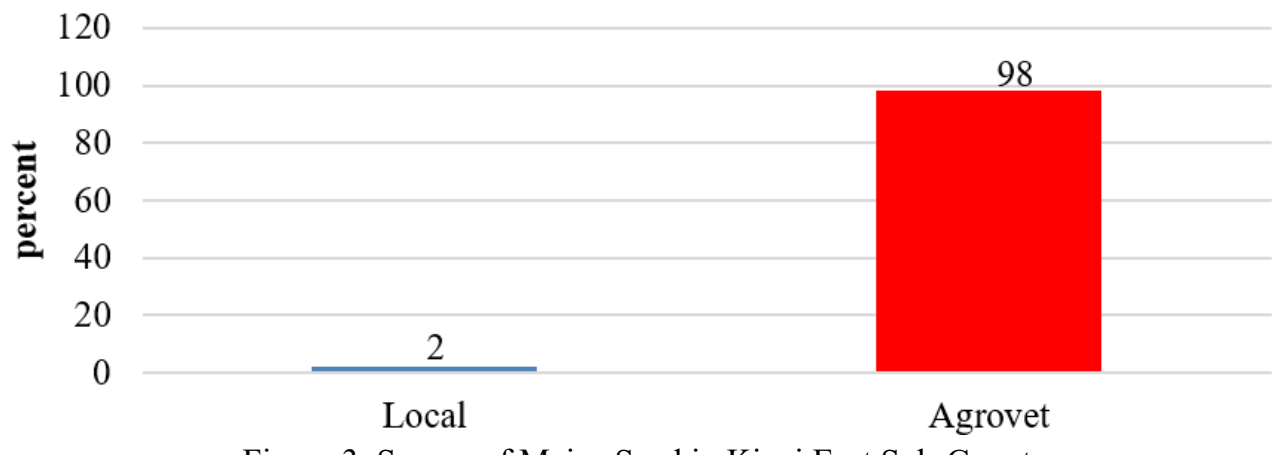

Figure 3. Source of Maize Seed in Kieni East Sub-County 
The researcher sought to establish the factors considered by farmers when choosing maize variety to plant. The findings in Figure 4, shows that most households (82.9\%) consider early maturity as the main reason for choosing the maize variety to plant. This was followed by $77 \%$ who consider high yielding maize variety and $57.5 \%$ who consider drought resistant maize. However, majority of the households (73.3\%) do not consider disease resistance as an important factor to put into consideration when choosing maize variety to plant. This shows that farmers are concerned about the environment and are planting crops that are suited to their surroundings. In Namibia, [38] in the 1980s found that farmers in Ovambo embraced new and early maturing varieties like pearl millet. This strengthened resilience to impacts associated with dry conditions in Namibia. In Kenya, in the maize seed sector in particular, farmers have the choice between different drought-resistant or early maturing varieties [26]. Despite the fact that certified seed production has expanded in Kenya over the last decade, utilization has remained low due to inadequate distribution and expensive prices [16]. Furthermore, the lack of control mechanisms encourages seed market misbehavior, further complicating access to high-quality seeds. Planting clean seeds helps in preventing the passing of negative traits from one season to the next. The long season cultivar requires greater than 150 days to maturity. Maize seeds selection by farmers therefore must conform to the rainfall variability vagaries of the sub-County in future as a step to increasing the yields.

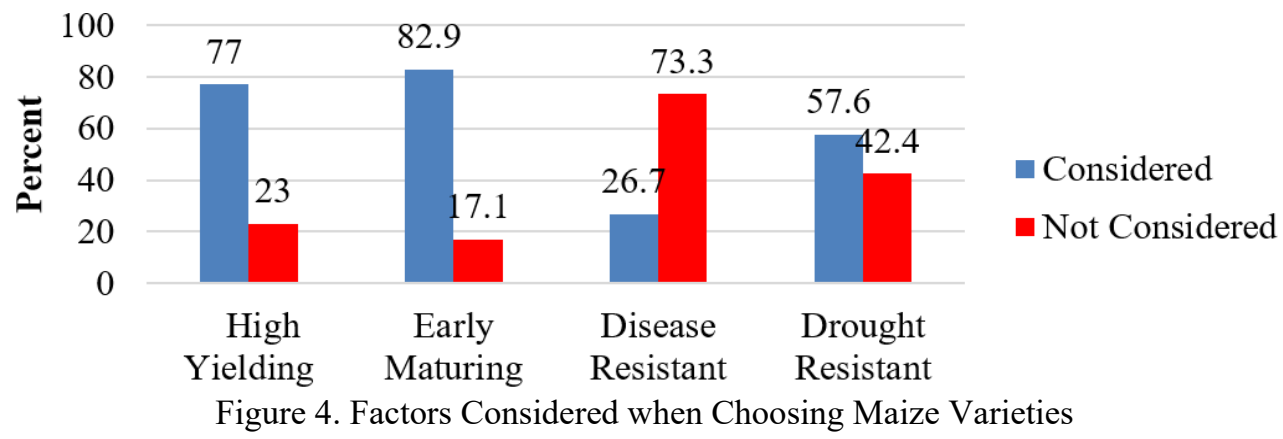

\subsubsection{Water Harvesting}

Based on the evidence showing a decline in rainfall amounts over the years as well as rainfall variability, the study sought to establish the measures of water harvesting by households in Kieni East Sub-County in Nyeri County. The findings in Figure 5 show that majority of the households do not harvest water. According to the ASDSP household survey of 2013, value addition (30.5\%) was more practiced than soil and water conservation (12.8\%). This may be attributed to the high perishability of the agricultural produce and inadequacy of storage facilities [32]. However, according to [51], Nyeri County is among the counties with the highest adaptation of strategies such as water harvesting. The common water harvesting strategy was found to be water tanks $(31.8 \%)$ followed by water pan (18.4\%). On the other hand, only $4.1 \%$ of the households use terraces with a similar proportion using grass strips, while only $1.4 \%$ stated that they use water wells. However, $92.2 \%$ of the household heads revealed that the strategies used for harvesting water are not sufficient to support maize farming. With structures like ridges, bunds and dams, rainwater is diverted, stored and used for irrigation at a later point in time [2]. Harvested water can be used for supplemental irrigation during dry spells to increase yield stability or for planting off-season cash crops to increase household income in the study area. However, high investment costs and knowledge requirements prevent smallholder farmers in SSA from adopting the technology [13]. Climate-proof strategies including better seasonal weather forecasts [18], improved cultivars and efficient rain-water management are critical for improving rain-fed agriculture. However, the ecological effects of some water harvesting measures like digging boreholes need to be looked into.

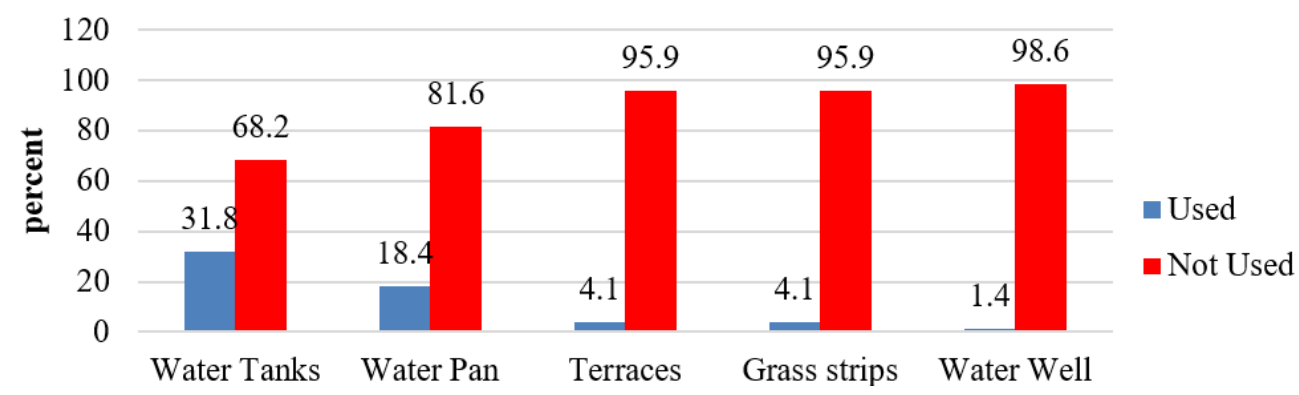

Figure 5. Water Harvesting Strategies in Kieni East sub-County 


\subsubsection{Use of Manure/Fertilizer in Maize Farming}

The study wanted to know whether the farmers had been using manure/fertilizer in their maize farming. The findings in Figure 6 show that, most respondents (92\%) use manure/fertilizer in their maize farming with only 8\% saying that they do not. This implies that farmers have invested in intensifying maize farming and improving soil fertility so as to increase maize yields. Mineral fertilizer and animal manure applied correctly can boost production and improve soil fertility [53]. In Kenya, the average application rate is $52.5 \mathrm{~kg} / \mathrm{ha}$, but in SSA, the rate is as low as $10 \mathrm{~kg} / \mathrm{ha}$ [53]. Smallholder farmers use artificial fertilizer less because of high input prices and ambiguous labeling [16]. Furthermore, fertilizer purchases are made prior to planting when farmers have already sold their previous season's harvest and risky expenditures are avoided [54]. Animal dung is only employed as a natural fertilizer by $24.3 \%$ of Kenyan farmers [16], and while this figure is greater in Kieni East sub-County, there is still a lot of room to improve soil conditions in the area. This may imply that farmers need low-cost options matching their adaptive capacity, or better access to credit to be able to bear the input costs like fertilizer at the start of the growing season.

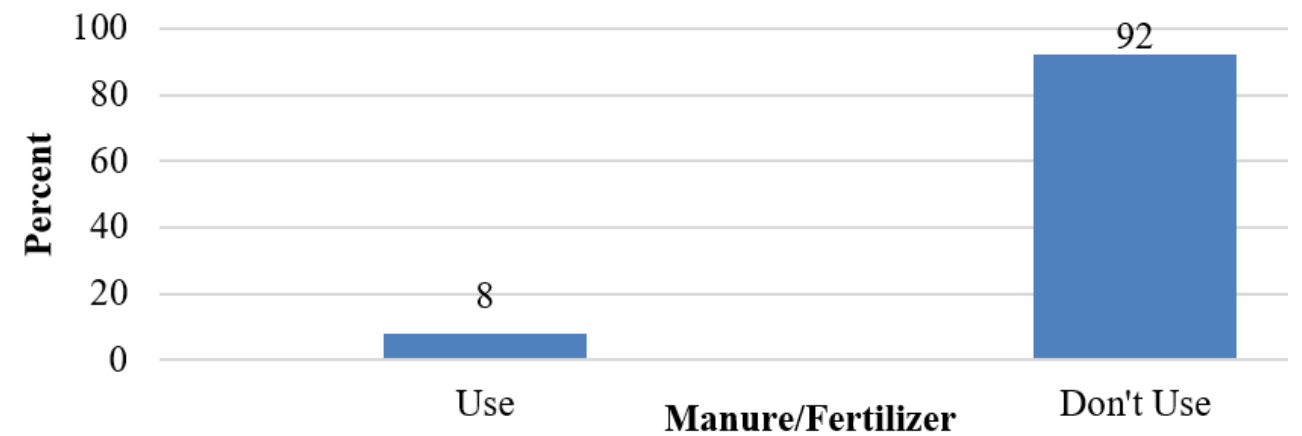

Figure 6. Use of Manure/Fertilizer in Kieni East Sub-County

The researcher sought to establish where the farmers get the manure for maize farming in Kieni East Sub-County in Nyeri County. The findings in Figure 7 shows that, majority of the households (81\%) get manure for maize farming from on-farm livestock. This was followed by $77.9 \%$ who buy off-farm manure. On the other hand, only $17 \%$ were found to use compost manure for maize farming.

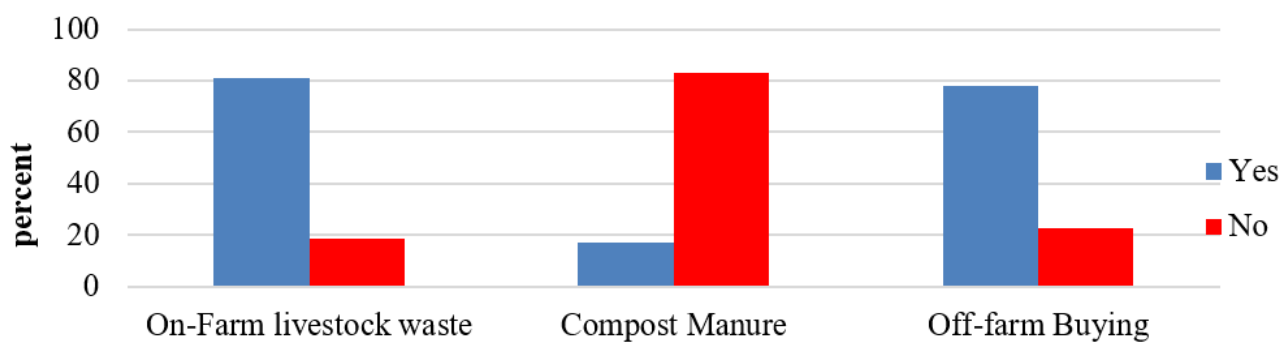

Figure 7. Source of Manure in Kieni East Sub-County

The study sought to establish where the farmers get the fertilizer for maize farming in Kieni East Sub-County in Nyeri County. The findings in Figure 8 show that most households $(77.9 \%)$ get their fertilizer from agro-vets. However, only a few were found to access the government subsidized fertilizers (34.6\%) and through donations (3.2\%). The use of fertilizers for sustained crop yield is integral given that in Kenya, farmers cultivate sub-optimal land and use the same plot season after season given that only $20 \%$ of land in Kenya is agriculturally productive. Limited use of fertilizers therefore is one of the major constraints in raising maize yields. [50] however indicated that high cost of inputs and insufficient credit services are among the most critical constraints to farmers to adopt the available seed-fertilizer technology packages, which is a widespread problem in Africa [54]. 


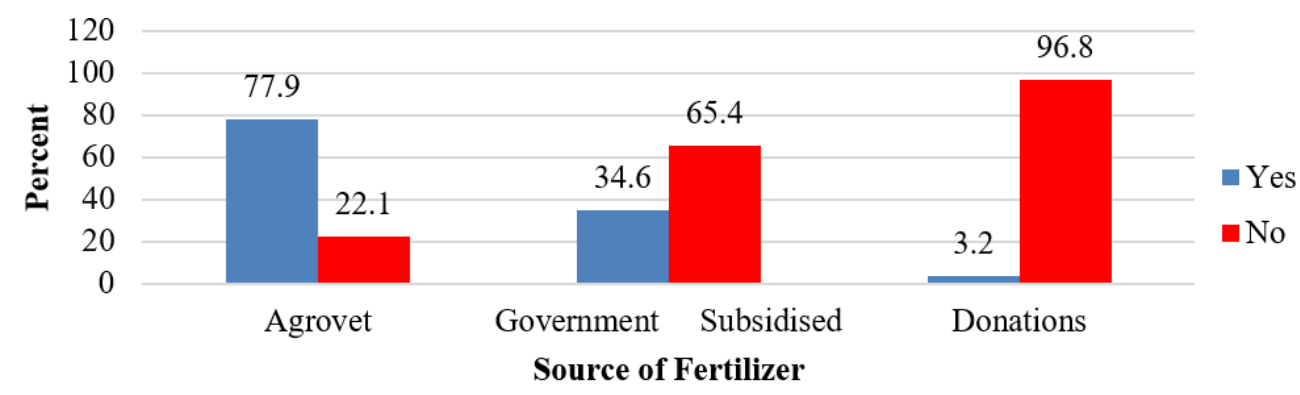

Figure 8. Source of Fertilizer in Kieni East Sub-County

\subsection{Analysis of Opportunities and Threats}

The findings in Figure 9 show that $31 \%$ of the respondents had been trained on maize farming methods while $69 \%$ were not trained.

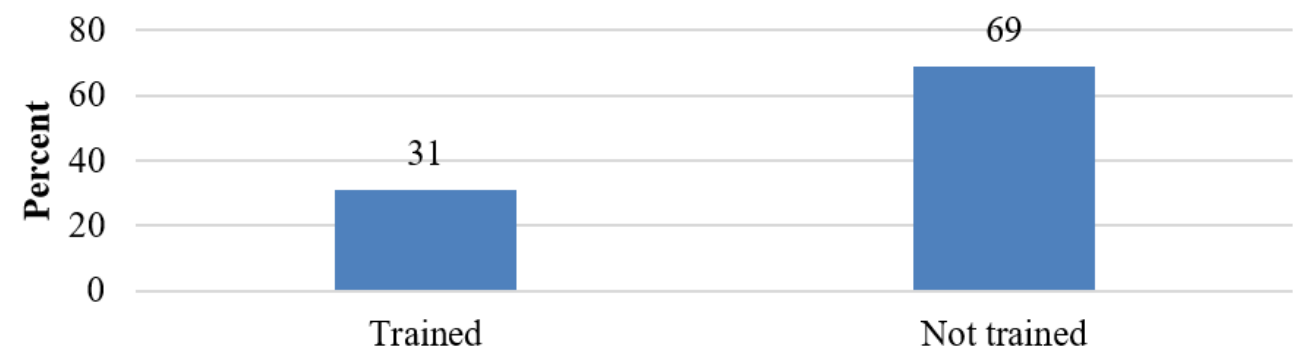

Figure 9. Training on Maize Farming

The study also revealed that there are several sources of training on maize farming. According to Table 5, the respondents indicated to have received training from the media (43.5\%), government extension officers (29.6\%), and private service provider $(10.2 \%)$ with only $(10.2 \%)$ from private service provider. The findings support the argument by [36], that all channels of communication should be utilized to ensure that farmers receive the vital information on time to enable then to plan well. This will reduce the effects of rainfall variability by ensuring that farmers make informed decisions in maize farming. Extension officers should educate the farmers on the importance of seasonal weather updates and also update them from time to time. When extension officers are few, farmers lack the much needed advice on the scientific methods of farming which leads to low yields.

Table 5. Source of Training on Maize Farming

\begin{tabular}{lcc}
\hline Source of Training & Frequency & Percent \\
\hline Friends & 18 & 16.7 \\
Government extension officers & 32 & 29.6 \\
Private service provider & 11 & 10.2 \\
Media & 47 & 43.5 \\
\hline Total & $\mathbf{1 0 8}$ & $\mathbf{1 0 0 . 0}$ \\
\hline
\end{tabular}

The study sought to establish whether the household heads required additional training on maize farming. According to Figure 10, majority of the respondents ( $86 \%$ ) indicated that they would like to get additional training on maize farming on different maize varieties, their growth cycles, when to plant for optimal yields, on their spacing when planting, as well as their fertilizer requirements among other things. This desire could be attributed to the fact that the extension agricultural officers in the area were inadequate to inform the farmers on rainfall onset and cessation, and generally on good maize farming practices. This will help farmers make informed decisions on when to plant and when to harvest for optimal yields. Training of farmers especially on the importance planting in time should be intensified to utilize the available rains at the crops' different stages of growth like during flowering and maturity. One of the most frequently recognized variables of adaptation is access to extension services [5]. Several studies have also demonstrated the importance of regular training in improving the existing levels of farmers' knowledge in the SSA region [1]. In SSA, a lack of knowledge was discovered to be a significant 
barrier to adaptation [41]. As a result, agricultural extension is likely to be linked to climate change adaptation methods. The Nyeri Meteorological Department needs to train extension officers in the use and interpretation of forecast information especially on rainfall onset and cessation so that the information can be disseminated to the farmers. This can help improve maize yields because the farmers can optimize the rainfall seasons. By successfully engaging communities with climate information, farmers are empowered to plan their livelihood activities accordingly, including what to plant, when to plant, when to intensify, when to diversify etc. [18,7].

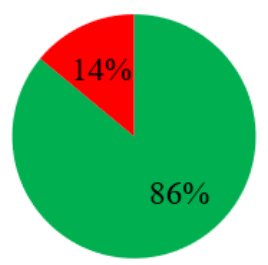

Require

Not required

Figure 10. Need for Additional Training

The researcher sought to establish the role played by the county government in assisting farmers overcome climate hazards in Kieni East Sub-County in Nyeri County. As shown in Table 6, the study established that the leading role of the county government was constructing dams (43.4\%), supplying fertilizers and seeds to farmers (37.9\%) as well as drilling boreholes (18.6\%). The Ministry of Agriculture is currently supporting the establishment of dams and pans in an attempt to deal with the impact of rainfall variability in semi-arid areas, Kieni East sub-county included even though currently they are inadequate and they also dry up during the dry season. [44] discussed seed fair as a drought recovery strategy in semi-arid South-East Kenya. The study considered seeds fair a better coping strategy to impacts of drought than food relief.

Table 6. Role of Nyeri County Government on Maize Farming

\begin{tabular}{lll}
\hline Functions & Frequency & Percent \\
\hline Supplying fertilizers and seeds to farmers & 55 & 37.9 \\
Sinking bore-holes & 27 & 18.6 \\
Dam construction & 63 & 43.4 \\
\hline Total & $\mathbf{1 4 5}$ & $\mathbf{1 0 0 . 0}$ \\
\hline
\end{tabular}

The researcher sought to establish how farmers in Kieni East Sub-County in Nyeri County respond to climate hazards. Majority of the respondents as shown in Table 7 implied that farmers plant early maturity maize varieties, $32.7 \%$ plant drought resistant seeds, $22.2 \%$ engage in alternative farming activities while $8 \%$ engaging in other economic activities. These act as a buffer in times of extreme climate events, especially when the rains fail. Studies have demonstrated that different asset bases can lead to divergent adaptation strategies among households in a single community [23]. [20] argue that maintaining a variety of strategies is an important tool in allowing farming to survive in climate variations. This is because some of these approaches have been used for thousands of years to minimize risk and ensure at least some productivity during unfavorable years. Climate-proof strategies including better seasonal climate forecasts [18], improved cultivars and efficient rain-water management are critical for improving rain-fed agriculture. Taking these findings into account, it would be sensible to place a higher priority on developing livelihoods that will allow farmers to manage better with current rainfall variability as a first step toward future climate change adaptation. The planting time is very important for it gives the plant an opportunity to mature before the dry spell.

Table 7. Smallholder Farmers Response to Climate Hazards

\begin{tabular}{lll}
\hline Response & Frequency & Percent \\
\hline Engage in alternative farming activities & 72 & 22.2 \\
Planting drought resistant seeds & 106 & 32.7 \\
Planting early maturing varieties & 120 & 37.0 \\
Engaging in other economic activities & 26 & 8.0 \\
\hline Total & $\mathbf{3 2 4}$ & $\mathbf{1 0 0 . 0}$ \\
\hline
\end{tabular}




\section{Conclusion}

The paper indicates that farmers use several strategies that include getting improved varieties of seeds, seeking training on effective maize production, harvesting water, using manure and fertilizers. The fertilizers were mainly from the agro-vets while the manure was gotten from on-farm livestock waste. Farmers were found to respond to climate hazards by planting maize varieties that are early maturing and drought resistant as well as engaging in alternative farming activities and other economic activities.

\section{Recommendtions}

There is a need for livelihood improvement programs to consider not just people's preferences, but also the suberratic County's rainfall. All stakeholders involved in climate and agriculture, both governmental and nongovernmental should work hand in hand to build the capacity of farmers on advanced technologies meant to improve maize yields as well as mitigating extreme climatic conditions by providing agricultural credit and effective extension services. Thus devolved extension services should be strengthened, harmonized, standardized, prioritized and streamlined to meet its objectives in service delivery to the farmers. Appropriate/indigenous technologies should be promoted for adaptation by the smallholder maize farmers. Knowledge of seasonal rainfall variability should be complimented with the understanding of socio-economic factors that impede the sub-county's adaptive capacity The expected outcomes include improved farm management capabilities under conditions of climate risks where farmers will plan and manage weather risks, maximize productivity and minimize the environmental impacts of farming practices.

\section{Acknowledgement}

The authors would like to greatly thank the Ministry of Agriculture, Livestock and Fisheries, Nyeri County for providing the data which enabled the completion of this study and Kenyatta University for facilitating this study.

\section{References}

[1] Adolwa, I. S., Esilaba, A. O., Okoth, P., \& Mulwa, M. R. (2010). Factors influencing uptake of integrated soil fertility management knowledge among smallholder farmers in Western Kenya. $12^{\text {th }}$ KARI Biennial Scientific Conference: Transforming agriculture for improved livelihoods through agricultural product value chains. KARI headquarters. Pp. 1146-1152.

[2] Ali, A., Yazar, A., Aal, A. A., Oweis, T. and Hayek, P. (2010). Micro-catchment water harvesting potential of an arid environment. Agricultural Water Management, 98(1), 96-104. https://doi.org/10.1016/j.agwat.2010.08.002

[3] Bancy, M. M. (2000). The influence of climate change on maize production in the semi-humid areas of Kenya. Journal of Arid Environments, 46(4), 333-334. https://doi.org/10.1006/jare.2000.0699

[4] Below, T. B., Schmid, J. C., \& Sieber, S. (2014). Farmer's knowledge and perception of climatic risks and options for climate change adaptation; a case study from two Tanzanian villages. Regional Environmental Change, 22, 223-235. https://doi.org/10.1016/j.gloenvcha.2011.11.012

[5] Bryan, E., Ringler, C., Okoba, B., Roncoli, C., Silvestri, S., \& Hererro, M. (2013). Adapting Agriculture to Climate Change in Kenya: Household strategies and determinants. Journal of Environmental Management, 114, 26-35. https://doi.org/10.1016/j.jenvman.2012.10.036

[6] Claessens, L., Antle, J.M., Stoorvogel, J. J., Valdivia, R. O., Thornton, P. K., \& Hererro, M. (2012). A method for evaluating climate change adaptation strategies for small-scale farmers using survey, experimental and modeled data. Agricultural Systems, 111, 85-95. https://doi.org/10.1016/j.agsy.2012.05.003

[7] Carr, E. R., Abrahams, D., Arielle, T., Suarez, P., Koelle, B. (2015). Vulnerability assessments, identity and spatial scale challenges in disaster-risk reduction. Jamba. J. Disaster Risk Stud., 7(1), 1-17. https://doi.org/10.4102/jamba.v7i1.201

[8] Cooper, P. J. M., \& Coe, R. (2011). Assessing and addressing climate induced risk in Sub-Saharan rain-fed agriculture. Experimental Agriculture, 47(02), 179-184. https://doi.org/10.1017/S0014479711000019

[9] Deressa, T. T., Hassan, R. M., Ringler, C., Alemu, T., \& Yesuf, M. (2009). Determinants of farmer's choice of adaptation methods to climate change in the Nile Basin of Ethiopia. Global Environmental Change, 19(22) 248-255. https://doi.org/10.1016/j.gloenvcha.2009.01.002

[10] Di Falco, S. (2014). Adaptation to climate change in Sub-Saharan agriculture: assessing the evidence and rethinking the drivers. Eur. Rev. Agri. Econ, 41(3), 404-430. https://doi.org/10.1093/erae/jbu014

[11] Dube, T., Moyo, P., Ncube, M., \& Nyathi, D. (2016). The impact of climate change on agro-ecological based 
livelihoods in Africa: A review. Journal of Sustainable Development, 9(1), 256-267. https://doi.org/10.5539/jsd.v9n1p256

[12] FAOSTAT. (2010). FAOSTAT Agricultural Data. Retrieved from http://www.faostat.fao.org/

[13] Fox, P., Rockstrom, J., \& Barron, J. (2005). Risk analysis and economic viability of water harvesting for supplemental irrigation in semi-arid Burkina Faso and Kenya. Agricultural Systems, 83, 231-250. https://doi.org/10.1016/j.agsy.2004.04.002

[14] Gbetibouo, G. A. (2009). Understanding farmer's perceptions and adaptations to climate change and variability: The case of Limpopo Basin, South Africa. International Food Policy Research Institute. Discussion Paper 00849.

[15] Glennerster, R., Kremer, M., Mbiti, I. and Takavarasha, K. (2011). Access and Quality in the Kenyan Education System: A Review of the Progress, challenges and Potential Solutions. Retrieved $5^{\text {th }}$ July, 2012 from http://www.povertyactionlab.org/publication/access-and-quality-Kenyan-education-system.

[16] Government of the Republic of Kenya (GoK). (2009). Agricultural Sector Development Strategy (ASDS). 2009-2020. Nairobi, Kenya.

[17] Government of the Republic of Kenya (GoK). (2013). Vision2030: National Climate Change Action Plan 2013-2017. Nanyuki, Kenya.

[18] Hansen, J. W., Mason, S. J., Sun, L., \& Tall, A. (2011). Review of seasonal climate forecasting for agriculture in Sub-Saharan Africa. Experimental Agriculture, 47, 205. https://doi.org/10.1017/S0014479710000876

[19] Hickey, G. M., Pelletier, B., Brownhill, L., Kamau, G. M., \& Maina, I. N. (2012). Perface: Challenges and Opportunities for enhancing food security in Kenya. Food Security, 4, 333-340. https://doi.org/10.1007/s12571-012-0203-2

[20] Hoang, M. H., Namirembe, S., van Noordwijk, M., Catacutan, D., Öborn, I., Perez-Teran, A. S., Nguyen, H.Q., \& Dumas-Johansen, M. K. (2014). Farmer Portifolios, Strategic Diversity Management and Climate Adaptation: Implications for Policy in Vietnam and Kenya. Climate and Development, 6(3), 216-225. https://doi.org/10.1080/17565529.2013.857588

[21] Humphrey, A. (2004). SWOT analysis method and examples, with free SWOT template. Retrieved $12^{\mathrm{q}}$ August 2013 from http://www.businnessballs.com/swotanalysisfreetemplate.htm

[22] IPCC. (2014). Climate Change (2014). Impacts, Adaptation and Vulnerability: Contribution of Working Group II to the IPCC Fifth Assessment Report. Cambridge University Press, Cambridge.

[23]Jaetzold, R., Schmidt, H., Hornet, Z. B., \& Shisanya, C. A. (2007). Farm Management Handbook of Kenya Vol. 2, (2nd Edition). Central Ministry of Agriculture and GTZ, Nairobi.

[24] Jain, M., Naeem. S., Orlove, B., Modi, V., \& DeFries, R. S. (2015). Understanding the causes and consequences of differential decision-making in adaptation research: adapting to a delayed monsoon onset in Gujarat, India. Global Environmental Change, 31, 98-109. https://doi.org/10.1016/j.gloenvcha.2014.12.008

[25] Kabubo-Mariara, J., \& Fredrick, K. K. (2007). The economic impact of climate change on Kenyan crop agriculture. A Ricardian approach." Global and planetary change 57 (3): 319-330. https://doi.org/10.1016/j.gloplacha.2007.01.002

[26] KEPHIS (Kenya Plant Health Inspectorate Services). (2015). National Crop Variety List-Kenya. Retrieved November 17, 2015 from http://www.kephis.org/images/VarietyList/updatejuly2015.pdf

[27] KNBS. (2010). Population and Housing Census, Nairobi: Kenya Central Bureau of Statistics.

[28] Kuyiah, J. W. (2007). Economic analysis of smallholder agricultural production under conditions of risk: the case of Vihiga and Kilifi Districts in Kenya. MSC Thesis, Egerton University, Kenya.

[29] Le Dang, H., Li, E., Bruwer, J., \& Nuberg, I. (2013). Farmers' perceptions of climate variability and barriers to adaptation:lessons learned from an exploratory study in Vietnam. Mitigation and Adaptation Strategies for Global Change, 19, 531-548. https://doi.org/10.1007/s11027-012-9447-6

[30] Micah, B., \& Absalom, M. (2014). Factors Influencing the Choice pf Climate Change Adaptation Strategies by Households: A case of Mpolonjeni Area Development Programme (ADP) in Swaziland. Journal of Agricultural Studies, 2(1), 2166-0379. https://doi.org/10.5296/jas.v2i1.4890

[31] Mintewab, B., Abe, D. B., Zenebe, G., \& Livousew, B. (2013). Social Capital, climate change and soil conservation investment: panel data evidence from the Highlands of Ethiopia. Grantham Research Institute 
on Climate Change and the Environment. Working Paper No.115.

[32] MoALF. (2016). Climate Risk Profile for Nyeri. Kenya County Climate Risk Profile Series. The Kenya Ministry of Agriculture, Livestock and Fisheries (MoALF), Nairobi, Kenya.

[33] Momanyi, S., Mutai, N., \& Bii, J. (2012). Attracting young people to farming. Agfax. Reporting science in Africa.

[34] Moock, P. (1973). Managerial ability in small-farm production: an analysis of maize yields in the Vihiga Division of Kenya. PhD Thesis (published) Columbia University, USA.

[35] Mohajan, H. K. (2014). Food and nutrition scenario of Kenya. American Journal of Food and Nutrition, 2(2), 28-38.

[36] Muga, M. (2010). Climate Change: A Major Challenge and Revelation for EA Nationals. A Journal on Resource, Reflection and Discourse for Sustainable Development, 32, 201-207.

[37] Ndegwa, W., Rao, K. P. C., Hgugi, R. K., \& Kwena, K. (2010). Improving farmer adaptive capacity by integrating local and indigenous knowledge in climate forecasting and adaptive response. Adaptation Insights, 4. $\quad$ Retrieved from http://www. idrc.ca/EN/Programs/Agriculture_and_the_Environment/Climate_Change_and_Adaptation_in_Africa/Docu ments/ Adaptation-Insights-Kenya-local-climate-forecasting.pdf

[38] Newsham, A. J., \& Thomas, D. S. G. (2011). Knowing, farming and climate change adaptation in NorthCentral Namibia. Global Envi ronmental Change, 21(2), 760-770. https://doi.org/10.1016/j.gloenvcha.2010.12.003

[39] Niang, I., Ruppel, O. C., Abdrado, M., Essel, A., Lennard, C., Padgham, J. et al. (2014). “Africa” in Climate Change 2014: Impacts, adaptations, and vulnerability. In: Contribution of Working Group II to the Fifth Assessment Report of the Intergovernmental Panel on Climate Change (pp 1199-1265). Cambridge/New York: Cambridge University Press.

[40] Odame, H. H., Hafkin, N., Wesseler, G., \& Boto, I. (2002). Gender and Agriculture in the Information Society. International Service for National Agricultural Research Briefing Paper no. 55. The Hague, Netherlands: ISNAR.

[41] Ofuoku, A. U. (2013). Rural farmers' perception of climate change in central agricultural zone of Delta State, Nigeria. Indonesian Journal of Agricultural Science, $12(2), \quad 63-69$. https://doi.org/10.21082/ijas.v12n2.2011.63-69

[42] Ogalleh, S., Vogl, C., Eitzinger, J., \& Hauser, M. (2012). Local Perceptions and Responses to Climate Change and Variability: The case of Laikipia District, Kenya. Sustainability, 4, 3302-3325. https://doi.org/10.3390/su4123302

[43] Ogola, O., Milton, W., Ayieko, A., Orawa O., \& Kimani, W. (2011). Analysis of fertilizer use in potato production in Nakuru district, Kenya. Africa Journal of Agriculture, 6(16), 3672-3677.

[44] Orindi, V. A., \& Ochieng, A. (2005). Seed Fairs as a Drought Recovery Strategy in Kenya. Institute of Development Studies, 36(4), 87-102. https://doi.org/10.1111/j.1759-5436.2005.tb00236.x

[45] Osbahr, H., Dorward, P., Stern, R., \& Cooper, S. (2011). Supporting agricultural innovation in Uganda to respond to climate risk: Linking climate change and variability with farmer perceptions. Experimental Agriculture, 47, 293-316. https://doi.org/10.1017/S0014479710000785

[46] Peacock, C., Jowett, A., Dorward, A., Poulton, C., \& Urey (2004). Reaching the poor: A call to Action, Investment in Smallholder Agriculture in Sub-Sahara Africa. London: Farm-Africa.

[47] Rurinda, J., Mapfumo, P., van Wijk, M. T., Mtambanengwe, F., Rufino, M.C., Chikowo, R., \& Giller, K. E. (2014). Comparative assessment of maize, finger millet and soghurm for household food security in the face of increasing climatic risk: European Journal of Agronomy, 55, 29-41. https://doi.org/10.1016/j.eja.2013.12.009

[48] Simelton, E., Quinn, C. H., Batisani, N., Dougill, A. J., Dyer, J. C., Fraser, E. D. G., Mkwambisi, D., Sallu, S., \& Stringer, L. C. (2013). Is rainfall really changing? Farmer's perceptions, meteorological data, and policy implications. Climate and Development 5, 123-138. https://doi.org/10.1080/17565529.2012.751893

[49] Sombroek, W. G., Braun, H. M. H., \& van der Pouw, B. J. A. (1982). Exploratory soil map and agro-climatic zone map of Kenya.E.I Report. Kenya Soil Survey, Nairobi, Kenya. 
[50] Spielman, D. J., Kelemwork, D., \& Alemu, D. (2011). Seed, Fertilizer and Agricultural Extension in Ethiopia. Ethiopian strategy support program (ESSP II), Working Paper 20. International Food Policy Research Institute, Washington, D.C. Smit, B., Wandel, J. (2006). Adaptation, adaptive capacity and vulnerability. Global Environmental Change, 61, 282-292. https://doi.org/10.1016/j.gloenvcha.2006.03.008

[51] Syomiti, M., Maranga, E., Obwoyere, G., Getachew, G., Dana, H., Beatrice, M., et al. (2015). The adaptive and coping strategies of pastoralists to climate change in Baringo, Laikipia and Nyeri Counties of Kenya. Livestock Res. Rural Dev., 27, 248.

[52] Thornton, P. K., Jones, Alagarswamy, G., Andresen, J., \& Herrero, M. (2010). Adaptation to climate change: Agricultural system and household impacts in East Africa. Agricultural Systems, 103, 73-82. https://doi.org/10.1016/j.agsy.2009.09.003

[53] Tittonel, P., Corbeels, M., van Wijk, M. T., Vanlauwe, B., \& Giller, K. E. (2008). Combining Organic and Mineral Fertilizers for Integrated Soil Fertility Management in Smallholder Farming Systems of Kenya: Explorations Using the Crop-Soil Model FIELD. Agronomy Journal, 100, 1511-1526. https://doi.org/10.2134/agronj2007.0355

[54] Tittonel, P., \& Giller, K. E. (2013). When yield gaps are poverty traps: The paradigm of ecological intensification in African smallholder agriculture. Field Crops Research, 143, 76-90. https://doi.org/10.1016/j.fcr.2012.10.007

[55] UNDP. (2010). Gender Climate Change and Community Based Adaptation. UNDP, New York.

[56] UNEP. (2011). Towards a Green Economy: Pathway to Sustainable Development and Poverty Eradication, United Nations Environment Programme. Retrieved from http://www.unep.org/green-economy

[57] USAID. (2010). Staple Foods Value Chain Analysis Country Report-Kenya. January, 2010.

[58] Waha, K., Muller, C., Bondeau, A., Dietrich, J. P., Kurukulasuriya, P., Heinke, J., \& Lotze-Campen, H. (2013). Adaptation to climate change through the choice of cropping system and sowing date in Sub-saharan Africa. Global Environmental Change, 23, 130-143. https://doi.org/10.1016/j.gloenvcha.2012.11.001

[59] Wamicha, W. N. (1993). Soil Erosion Hazards in Kieni Division, Kenya.

[60] Wood, S. A., Jina, A. S., Jain, M., Kristjanson, P., \& De Fries, R. S. (2014). Smallholder farmer cropping decisions related to climate variability across multiple regions. Global Environmental Change, 25, 163-17. https://doi.org/10.1016/j.gloenvcha.2013.12.011

\section{Copyrights}

Copyright for this article is retained by the author(s), with first publication rights granted to the journal.

This is an open-access article distributed under the terms and conditions of the Creative Commons Attribution license (http://creativecommons.org/licenses/by/4.0/). 